\title{
CHANGES IN DIAGNOSTIC PATTERNS OF DEPRESSION AMONG FAMILY PHYSICIANS IN LATVIA AFTER PARTICIPATING IN THE EDUCATION COURSE ON DEPRESSION DEVELOPED WITHIN THE NATIONAL RESEARCH PROGRAMME BIOMEDICINE 2014-2017: PRELIMINARY RESULTS
}

\author{
Elmārs Rancāns ${ }^{1, \#}$ and Anda K̦īvìte-Urtāne ${ }^{2}$ \\ ${ }^{1}$ Department of Psychiatry and Narcology, Rīga Stradinš University, 2 Tvaika Str., Rīga, LV-1005, LATVIA \\ 2 Department of Public Health and Epidemiology, Rīga Stradiṇš University, 9 Kronvalda Blvd, Rīga, LV-1010, LATVIA \\ \# Corresponding author, elmars.rancans@rsu.lv
}

Communicated by Modra Murovska

\begin{abstract}
Annually, $7.9 \%$ of the general population in Latvia are suffering from depression. According to the official statistics, less than 8000 persons a year have been treated for depression in the state-paid health care services while the National Research Programme (NRP) BIOMEDICINE 2014-2017 found that more than 70000 depressed patients annually are coming to family physicians (FPS) in Latvia. Within NRP researchers have developed an algorithm for diagnostics and treatment of depression and carried out ten educational courses for FPs all over Latvia in 2016. Data on the treatment of depression have been collected from the National Health Service (NHS) database from 01.01.2015 till 30.06.2017. Changes between the trained and control groups have been calculated for the time period before intervention - 2015-2016 and six months right after it. The "Depression School" was attended by 210 (15.2\%) out of 1382 FPs, in contract with the NHS, who signed in for the course on first-to-come basis. There were no statistically significant demographic differences between trained and control groups, except, a larger proportion of FPs from rural places vs. the capital city attended the courses. Comparing the trained and control groups, during the period before the intervention there were on average $0.96 \mathrm{vs} .0 .83$ depressive episodes (F32) and 3.26 vs.1.74 recurrent depressive disorder (F33) episodes in 1/2 year ( $\mathrm{p}<$ $0.001)$. Statistically significant increase was observed for F33 episodes $(+1.42, p<0.001)$, and numeric for F32 episodes $(+0.18, \mathrm{p}=0.36)$ in the trained group of FPs in 2017. In total this gave a statistically significant $(\mathrm{p}<0.001)$ increase by $43.6 \%$ of $F 33$ diagnoses following the education course on depression for family physicians. Further analysis of data to access sustainability of training effect after 12 and 24 months are underway.
\end{abstract}

Key words: depressive disorders, primary care doctors, educational programme.

Depressive disorders are highly prevalent in the general population and cause a major burden to the European society (Wittchen et al., 2011). It has been estimated that $6.9 \%$ of Europeans suffer annually from this disorder. A recent study in Latvia confirmed that the level in Latvia is even higher: $7.9 \%$ of the general population, or more than 115000 adults, in Latvia suffer from depressive disorder annually (Vrublevska et al., 2017). According to the official statistics, only 11821 persons a year have been treated for affective disorders within the state-paid health care services
(Pulmanis, 2016). The point prevalence of depression in the primary care was been estimated as $10.2 \%$ in the National Research Programme (NRP) BIOMEDICINE 2014-2017; this means that more than 70000 depressed patients annually visit family physicians (FPs) in Latvia (Rancans et al., 2018). However, the majority of them are not recognised and are not properly treated in primary health care, as in other countries (Bijl et al., 2004). There are several subjective and objective factors, like the presence of somatic complaints and low self-confidence of doctors in diagnostics 
and depression management, which diverts FPs from timely diagnostics and treatment of depression (Leff et al., 2017). Therefore, it is crucial to carry out specific educational programmes, complimented with screening instruments, treatment guidelines and algorithms for FPs in order to improve diagnostics and treatment of depression in primary care (Sielk et al., 2009; Sikorski et al., 2012). The aim of this study was to assess the efficacy of a specially designed "Depression School" on diagnostic patterns of depression among family physicians in Latvia.

Within the programme NRP BIOMEDICINE 2014-2017, a group of researchers developed an algorithm for diagnostics and treatment of depression, developed a specific educational programme, and during October-December 2016 presented ten educational courses for FPs all over Latvia. The education course was advertised through professional organisations and was offered to any FPs practicing in Latvia on the first-to-come basis. Data from the National Health Service (NHS) database from 01.01.2015 to 30.06.2017 on treatment episodes of depressive episode (F32) and recurrent depressive disorder (F33) in primary care services were analysed. Changes in the diagnostic patterns of depression between trained and control groups were assessed for the time period before education (2015-2016) and six months after the educational programme. For this, relative numbers of depression diagnoses and episodes were calculated per one physician per half-a-year (one person-half-a-year). The statistical significance of differences between groups was tested using the Chi-square test within OpenEpi software ( $p$ level chosen for statistical significance was 0.05).

The "Depression School" was attended by 210 (15.2\%) of 1382 FPs who were under contract with the NHS. The majority of trained physicians were women $(89.0 \%)$, half of them - younger than 55 years, $23.8 \%$ working in the capital city, $25.7 \%$ from other large cities, and $50.5 \%$ from rural areas. Of these factors, significantly different between the trained and control groups was that more FPs from rural areas vs. the capital attended the courses (Table 1).

During the period before the intervention (2015-2016), FPs diagnosed 4699 episodes of depressive (F32) and 10902 episodes of recurrent depressive disorder (F33), compared with 1130 and 3311 episodes, respectively, during the first half of year 2017. Comparing the trained and control groups, during the period before the intervention there was on average 0.96 vs. $0.83 \mathrm{~F} 32(p=0.33)$ and 3.26 vs. 1.74 F33 episodes in $1 / 2$ year $(p<0.001)$ (Fig. 1). There were no statistically significant changes between the two periods in a number of episodes for the control group. During the first half of 2017, there were statistically significant differences between trained and control groups - for F32 episodes 1.14 vs. $0.76(p=0.006)$ and F33 diagnoses 4.68 vs. 1.99 $(p<0.001)$, accordingly. An increase in the number of F32 episodes $(+0.18, p=0.36)$ and statistically significant increase was of $\mathrm{F} 33$ episodes $(+1.42, p<0.001)$ in the trained group of FPs was observed. There was a total increase by $43.6 \%$ ( $p<0.001$ ) of F33 diagnoses following the education course on depression.
Table 1

DESCRIPTION OF STUDY PARTICIPANTS IN THE TRAINED AND CONTROL GROUPS

\begin{tabular}{ll|c|c|c|c|c}
\hline \multirow{2}{*}{} & & \multicolumn{2}{c|}{$\begin{array}{c}\text { Trained } \\
\text { group }\end{array}$} & \multicolumn{2}{c|}{$\begin{array}{c}\text { Control } \\
\text { group }\end{array}$} & $\begin{array}{c}p \text { value } \\
\text { between } \\
\text { groups }\end{array}$ \\
\cline { 3 - 7 } Gender & Male & 23 & 11.0 & 140 & 11.9 & 0.69 \\
& Female & 187 & 89.0 & 1032 & 88.1 & \\
\hline \multirow{2}{*}{ Age } & Below 34 & 8 & 3.8 & 60 & 5.1 & 0.16 \\
& 35-54 & 98 & 46.7 & 467 & 39.8 & \\
\hline \multirow{2}{*}{$\begin{array}{l}\text { Localization } \\
\text { of workplace }\end{array}$} & Riga*\# & 50 & 23.8 & 421 & 35.9 & 0.003 \\
& Large cities* & 54 & 25.7 & 241 & 20.6 & \\
& Rural\# & 106 & 50.5 & 510 & 43.5 &
\end{tabular}

${ }^{*} p=0.003$, Riga vs. Large cities; $\# p=0.002$, Riga vs. Rural
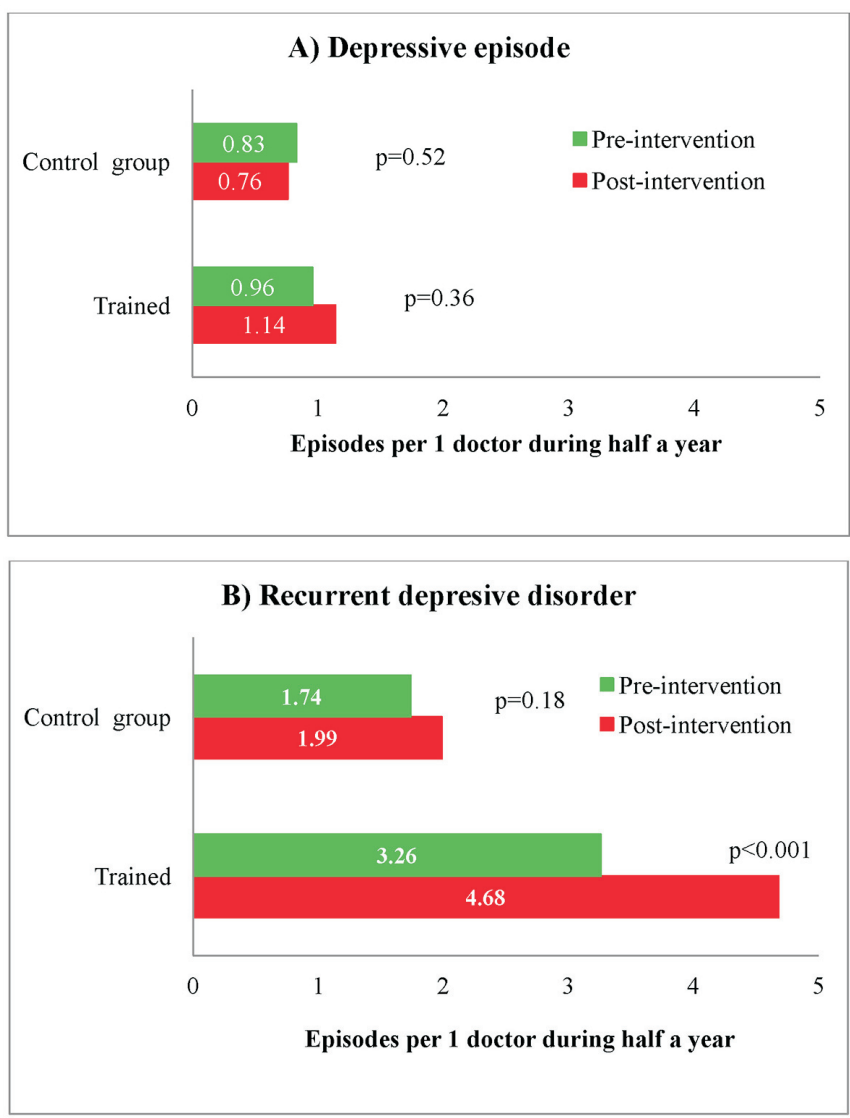

Fig. 1. Changes in the diagnostics patterns made by family physicians in half-a-year before and after the educational intervention: number of A) depressive and B) recurrent depressive disorder episodes per $1 / 2$ year.

Information regarding the impact of training of general practitioners on the diagnosis and management of depression presented in the international peer-reviewed literature is not unequivocal. Most studies show that the training of primary care physicians has an impact on their knowledge and attitudes towards depression but has very limited or no impact on the further daily clinical practices carried out by the family doctors (Gilbody, 2004; Vincente et al., 2007). However, some studies carried out outside Europe suggest that the training of general practitioners leads to an increase 
in the rates of new diagnoses of depression in primary care (Ayano et al., 2017). Nevertheless, all authors emphasise that primary care doctors play a major role in the detection, referral, and management of depressive disorders.

This is the first study carried out in Latvia that aimed to evaluate changes in the diagnostic patterns of mental disorders (depression in particular) determined by doctors, based on national registry data. Our study contributes to the understanding of the impact of training on the practices of family doctors. It shows that a training programme, if developed carefully, in a well-thought-out and nationally appropriate way, if provided interactively by highly qualified mental health professionals and accompanied by easy understandable and short print-out materials, can significantly increase the initiative of family doctors in diagnosis of depressive disorders. The preliminary results of our study showed a statistically significant increase in the rates of diagnosis of depressive disorders among trained practitioner. However, we will analyse the 12- and 24-month data to observe whether the impact of training retains a sustainable effect on doctors' practices. A further study will allow us to draw conclusions on the overall efficacy of the training programme and make recommendations to implement it as a regular training tool for family physicians.

\section{REFERENCES}

Benjamin, V., Kohn, R., Levav, I., Espejo, F., Saldivia, S., Sartorius, N. (2007). Training primary care physicians in Chile in the diagnosis and treatment of depression. J. Affect. Disord., 98 (1-2), 121-127.

Bijl, D., van Marwijk, H. W., de Haan, M., van Tilburg, W., Beekman, A. J. (2004). Effectiveness of disease management programmes for recognition, diagnosis and treatment of depression in primary care. Eur. J. Gen. Pract., $10(1), 6-12$

Ayano, G., D., Haile, K., Chaka, A., Haile, K., Solomon, M., Yohannis, K., Awoke, A., Jemal, K. (2017). Mental health training for primary health care workers and implication for success of integration of mental health into primary care: Evaluation of effect on knowledge, attitude and practices (KAP). Int. J. Mental Health Syst., 11, 63.

Gilbody, S. (2004). What is the evidence on effectiveness of capacity building of primary health care professionals in the detection, management and outcome of depression? WHO Regional Office for Europe, Health Evidence Network report, Copenhagen. Available at:

http://www.euro.who.int/Document/E85243.pdf (accessed 26 November 2018).

Leff, M. S., Vrubḷevska, J., Lūse, A., Rancāns, E. (2017). Latvian family physicians' experience diagnosing depression in somatically presenting depression patients: A qualitative study. Eur. J. Gen. Pract., 23 (1), 91-97.

Pulmanis, T., Japenina, S., Taube, M. (2016). Psihiskā veselība Latvijā 2015. gada [Mental health in Latvia in 2015]. Slimību kontroles un profilakses centrs, Rìga [Centre for disease prevention and control of Latvia] (in Latvian). 63 pp. Available at:

https://spkc.gov.lv/upload/Psihiska_veseliba_faili/psihiska_veseliba_ latvija_2015_gada.pdf (accessed 19 April 2017)

Rancans, E., Trapencieris, M., Ivanovs, R., Vrublevska, J. (2018). Validity of the PHQ-9 and PHQ-2 to screen for depression in nationwide primary care population in Latvia. Ann. Gen. Psychiatry, 17, 33.

Sielk, M., Altiner, A., Janssen, B., Becker, N., de Pilars, M. P., Abholz, H. H. (2009). Prevalence and diagnosis of depression in primary care. A critical comparison between PHQ-9 and GPs' judgement. Psychiatr. Prax., 36 (4), 169-174.

Sikorski, C., Luppa, M., Konig, H. H., van den Bussche, H., Riedel-Heller, S. G. (2012). Does GP training in depression care affect patient outcome? A systematic review and meta-analysis. BMC Health Serv Res, 12, 10.

Vrublevska, J., Trapencieris, M., Snikere, S., Grinberga, D., Velika, B., Pudule, I., Rancans, E. (2017). The 12-month prevalence of depression and health care utilization in the general population of Latvia. J. Affect. Disord., 210, 204-210.

Wittchen, H. U., Jacobi, F., Rehm, J., Gustavsson, A., Svensson, M., Jönsson, B., Olesen, J., Allgulander, C., Alonso, J., Faravelli, C., Fratiglioni, L., Jennum, P., Lieb, R., Maercker, A., van Os, J., Preisig, M., Salvador-Carulla, L., Simon, R., Steinhausen, H. C. (2011). The size and burden of mental disorders and other disorders of the brain in Europe 2010. Eur. Neuropsychopharmacol., 21 (9), 655-679.

\section{DEPRESIJAS DIAGNOSTICĒŠANAS PARADUMU IZMAIN̦AS ĢIMENES ĀRSTU PRAKSĒS LATVIJĀ PĒC VALSTS PĒTİJUMU PROGRAMMAS BIOMEDICINE 2014-2017 APMĀCİBAS KURSA DEPRESIJAS DIAGNOSTIKĀ UN ĀRSTĒŠANĀ REALIZĀCIJAS: PIRMIE REZULTĀTI}

Latvijā katru gadu ar depresiju slimo 7,9\% iedzīvotāju, taču valsts apmaksātajos veselības aprūpes dienestos katru gadu ar depresiju ārstējas ne vairāk kā 8000 iedzīvotāju. Pētījumā konstatēts, ka aptuveni 70000 pacientu ar depresiju gada laikā apmeklē savu ğimenes ārstu (Ĝ̣̄). Valsts pētījumu programmas BIOMEDICINE 2014-2017 ietvaros izstrādāti un 2016. gadā visā Latvijas teritorijā realizēti desmit apmācības kursi depresijas diagnostikā un ārstēšanā, kuri tika piedāvāti visiem praktizējošiem ǵimenes ārstiem. Pieteikšanās kursiem notika pēc pirmās rokas principa. No Nacionālā veselības dienesta (NVD) tika iegūti dati no primārās veselības ārstu ambulatorajiem taloniem par laika periodu no 2015. gada 1. janvāra līdz 2017. gada 30. jūnijam. Depresijas diagnostika periodā pirms intervences 2015.-2016. g. un pirmajos sešos mēnešos pēc izglītības programmas realizācijas tika salīdzināta starp apmācītajiem un visiem pārējiem G̣Ā. Apmācības kursus apguva $210(15,2 \%)$ no 1382 G̣Ā, kuri bija līguma attiecībās ar NVD. Pēc pamata demogrāfiskajiem rādītājiem abas grupas savā starpā neatškīīās, vienīgi apmācību izgāja lielāks procents Ĝ̣Ā no lauku teritorijām. Salīdzinot apmācīto un kontroles grupu, pirms intervences uz vienu ārstu vidēji bija 0,96 vs. 0,83 ( $p=0,3$ ) depresijas epizodes (F32) un 3,26 vs. 1,74 ( $p<0.001$ ) rekurentās depresijas (F33) epizodes pusgadā. 2017. gadā apmācīto grupā ir pieaudzis F33 $(+1,42, p<0,001)$ un arī F32 epizožu skaits $(+0,18, p=0,36)$. Apmācīto Ĝ̣̄ grupā novērots F33 epizožu diagnostikas pieaugums par 43,6 \% ( $p<0,001)$. Pētījumā tika novērots statistiski nozīmīgs depresiju diagnosticēšanas pieaugums pēc apmācības kursa depresijas diagnostikā un ārstēšanā realizācijas. Plānots izanalizēt šo tendenču noturību pēc 12 un 24 mēnešiem, lai varētu izvērtēt kopējo programmas efektivitāti un lemt par tās ieteikšanu regulārai Ģ̣̄ izglītošanai. 